\title{
A szóbeliség fontossága és ennek lehetőségei az alsó tagozat bevezető szakaszának nyelvtanításában
}

\author{
Nagy Katalin Gabriella
}

Platanus Schule, Berlin

\begin{abstract}
Jelen tanulmány elméleti alapvetésként a kisgyermek nyelvi fejlödését vizsgálja egészen a magzati kortól, mivel az anyanyelv kialakulásának folyamata meghatározza a további nyelvek elsajátításának folyamatát is. Röviden bemutatja és megkísérli párhuzamba állitani a több anyanyelven felnövő és az iskolai körülmények között idegen nyelvet tanuló kisgyermek nyelvelsajátítását. Ezekböl következően tárgyalja a beszéd fontosságát a nyelvtanulás és -tanitás korai szakaszában, melynek lehetőségeit konkrét, gyakorlati példákon keresztül mutatja be. Az olyan ismert módszereket, mint a párbeszéd, a gyermekdalok, mondókák alkalmazása, képsorok rendezése és leírása, megkísérli új, gyermekközpontú nézőpontból bemutatni.
\end{abstract}

\section{Bevezetés}

\subsection{A nyelvelsajátítás folyamata a magzati kortól a kisgyermekkorig}

Mielőtt a kisgyermekkori idegennyelv-tanítás kérdésével foglalkozhatnánk, ismernünk kell a gyermek anyanyelv-elsajátításának szakaszait, hiszen minden későbbi nyelvtanulási folyamat erre épül. A kisgyermek még nem tudatos beszéd- és nyelvelsajátítása példát kell, hogy adjon a későbbi nyelvtanítás módszereinek megválasztásakor.

A gyermek életének egészen korai szakaszára, egyes modern kutatások szerint egészen a méhen belüli fejlődésig kell visszamennünk, ha meg akarjuk találni a nyelvi fejlődés gyökereit. Megfigyelések kimutatták, hogy már az újszülött csecsemők sírása különböző nyelvterületek szerint eltérő 'akcentust' mutat. A Würzburgi Egyetem kísérleteiben néhány napos francia és német csecsemők sírását hasonlították össze, melyből egyértelmúen kiderült, hogy a csecsemők az anyaméhben kapott akusztikus inputot a születést követően szinte azonnal használják. A Berlin-Brandenburgi Tudományos Akadémia professzora Werner Mende és Prof. Dr. Kathleen Wermke (Würzburgi Egyetem) ezen kísérletek alapján bizonyították, hogy a nyelv dallamára való igen korai érzékenység segíti a gyermeket később az anyanyelv elsajátításában (Wermke, 2007). A csecsemő - és már a magzat is - elsősorban az anya beszéde és a környezetéé között differenciál, tehát születésétől fogva különválik az 'anya nyelve' minden mástól.

Itt említeném meg, hogy a két nyelven felnövő gyermek ugyanígy személyhez köti a különböző hallott nyelvi mintákat. Az első években tehát nincs annak tudatában, hogy két nyelvet használ, hanem, hogy más-más személyhez szól (Kersten, 2010).

A körülbelül kilenc hónapos korig tartó preverbális szakasz után a gyermek hangadása már olyannyira differenciálódik, hogy képes lesz egyes szavakat kiejteni, egyéves korra pedig már környezet figyelmének felkeltésére használja ezeket. A második életévhez közelítve a szókincs robbanásszerüen megnő, és a gyermek ötéves koráig körülbelül napi tíz szóval bővül. A 'távirati beszéd' értelmes, kezdetben két-háromszavas, később mellé- majd alárendelő tagmondatokból felépülő mondatokká alakul. Három éves kor körül kezdődik a nyelvtani szabályok észlelése, mely leginkább ezek túláltalánosítása, hamis analógiák alkalmával figyelhető meg. A kisgyermek ezután 
fokozatosan elsajátítja a különböző idősíkok kifejezésének módját. A nyelvtani szabályok további bővülésével a gyermek hétéves korára már képes helyesen használni a nyelvet, akkor a nyelvtani, szintaktikai ismeretek szerzése tulajdonképpen lezárul, lényegében már nem változik a későbbiekben - nem úgy, mint maga a nyelvelsajátítás (language acquisition, Krashen, 1982), mely egész életünket végigkísérő folyamat.

\subsection{A második nyelv elsajátításának lehetőségei}

Amint már fent említésre került, az ember képes két nyelv egyidejü tökéletes elsajátítására gyermekkorban. Amennyiben az otthon két nyelvet beszélő gyermek a szülői házon kívül ismét más nyelvi környezetbe kerül, a harmadik nyelvet is nehézségek nélkül képes lesz kortársai és nevelői által elsajátítani. A harmadik nyelv birtoklásának szintje is az adott nyelvi közegben eltöltött időtől és annak rendszerességétől függ.

A szülőktől történő, a korai nyelvelsajátításon kívüli nyelvtanulás esetében azonban már figyelembe kell venni egy fontos tényezőt, mégpedig a gyermek életkorát. Az e szakasz meghatározásával foglalkozó elmélet (Critical Period Hyphothesis) több változata is ismert, mivel a nyelvtanulásra való nyitottság időtartamának meghatározásakor eltérnek a vélemények (Lenneberg, 1967; Oyama, 1976). Egyes szakértők szerint az első hét életév után bezárul ez az 'ablak', mások viszont azt sem tartják kizártnak, hogy akár 14 éves korig elsajátítható a második (harmadik...) nyelv tökéletes szinten (Singleton, 1995). A nyelvpedagógusok számára nagyon fontos üzenete van ezen elmélet minden változatának: minél korábban kezdjük el a második nyelv elsajátíttatását, annál eredményesebb lesz hosszú távon, annál nagyobb esélye lesz a gyermeknek anyanyelvi, vagy ahhoz közli szinten elsajátítani az idegen nyelvet. A kritikus periódus elméletéből következően - egy nyelv felvételére a kisgyermek a legérzékenyebb, amely időszakban egyedül beszéd és hallás által tanul - a korai idegennyelv-tanításnak is kizárólagosan szóbeliségen kell alapulnia. Így tudjuk legjobban kihasználni a gyermek azon képességét, hogy intuitív módon sajátítsa el a nyelvet akár óvodai-iskolai keretek között is. E felfogás a legtöbb általános iskolában ma már magától értetődő, ezért a következőkben a szóbeli nyelvtanulás különböző lehetőségeit mutatom be.

\section{Lehetőségek a szóbeliség kihasználására az alsó tagozatos idegennyelv- oktatásban}

Sokan keresik az ideális nyelvóra titkát, még többen állítják, hogy nem létezik ilyen, hiszen rengeteg apró mozzanatból épül fel egy tanóra, és számtalan szempontot kell, hogy figyelembe vegyen az azt tervező tanító. És persze vannak olyan alapkövetelmények, melyek fölött nem lehet elsiklani: a megfelelő tanítói végzettség, a tanítandó nyelvet igényesen és helyesen beszélő, a mai nyelvhasználatot és kulturális közeget ismerő pedagógus. Egy nyelvtanítási konferencia alkalmával azonban volt szerencsém megismerni egy olyan vezérlő elvet, ami nagyban meghatározza egy nyelvóra kvalitását - általában is, az alsó tagozatra nézve pedig sokszorozottan igaz. Dr. Norbert Becker német nyelvpedagógus (Mainz, Private Hildegardisschule) vállalkozott arra, hogy megadja a jó idegennyelvóra receptjét, azt a komponenst, amely alapján szinte pontosan mérhető a nyelvóra minősége. Állítása szerint a nyelvóra minősége azzal mérhető, hogy a tanulók mennyi időt töltenek az adott nyelven történő beszéddel, mennyi lehetőségük adódik aktívan használni azt. Mindeközben kizárólag az elsajátítandó nyelven érjék őket impulzusok (Becker, 2010). Ha visszagondolunk az 
A szóbeliség fontossága és ennek lehetőségei az alsó tagozat bevezető szakaszának nyelvtanításában

előbbiekben felvázolt beszédfejlődési folyamatra, láthatjuk, hogy Dr. Becker elmélete tökéletesen egybehangzik azzal. Akár az anyanyelv-elsajátítási szakaszban, a gyermek hallás és utánzás - tehát beszéd - segítségével kell, hogy elsajátítsa a nyelvet. (Felsőbb tagozaton a nyelv használata már tovább differenciálódik az írás és olvasás eszközszerü alkalmazásával, de az első években a beszéd mint nyelvhasználati eszköz kizárólagos jelentőségü.)

Azzal is tisztában kell lennünk az első hónapokban, hogy az idegen nyelvvel akkor először találkozó kisgyermeknek az idegennyelv-órák rengeteg új ingert, tapasztalatot jelentenek, pusztán az aktív hallgatás által, de akár a tudattalanul magragadt tartalmak is. Akár az anyanyelv elsajátításának kezdeteikor, a hallgatásnak itt is nagy szerepe van, melynek során a beszédprodukcióhoz szükséges passzív tudás halmozódik fel. Mivel ezt az első időszakot még nem az aktív nyelvhasználat jellemzi döntően, csendes szakasznak nevezzük (Silent Period). Az említett tartalmak aktivizálódásának ideje egyénenként igen eltérő lehet, ezért fontos, hogy kezdetben ne erőltessük, és semmiképpen ne várjuk el minden gyerektől egyformán a nyelvi aktivitást.

E periódusnak az időtartama a személyiség mellett a nyelvvel való érintkezés intenzitásától és gyakoriságától is függ, így tehát egy két tanítási nyelvű iskolában hamarabb kezdenek önállóan kommunikálni a tanulók. Azonban az első néhány hónap minden esetben különleges időszak, mely a pedagógustól különleges érzékenységet igényel.

Mindezen feltételek ismeretében álljon itt néhány lehetőség arra, hogy tehetjük beszédben gazdagabbá, és így jobb minőségűvé nyelvoktatásunkat.

\subsection{Párbeszédek}

A szóbeli megnyilvánulások egyik legalapvetőbb formája a párbeszéd, melyet a legelső nyelvórától kezdve használhatunk. És hogy milyen 'párbeszédeket' építhetünk fel a legkisebbeknél? Gondoljunk a legegyszerübb kifejezésekre: kezdhetjük az üdvözléssel, majd ezt követheti a bemutatkozás. A gyermekcsoporttal kört alkotva bevezetjük kívánt üdvözlési formulát, legyen ez olyan egyszerü, mint a „Hallo!”. Megfelelő mozdulatokkal kísérve, többször elismételjük, elénekeljük - erröl majd a későbbiekben részletesebben lesz szó -, majd következhet az alkalmazás. Nagyszerü gyakorlat erre az a játék, melynek során a gyerekek bizonyos zenére a teremben szabadon mozognak. Amikor a zene egy rövid időre megáll, a gyerekeknek üdvözölniük kell egymást az adott kifejezésekkel. Amikor a gyerekek már megismerték a játék menetét, további mozzanatokkal tehetjük érdekesebbé azt: a következő megálláskor mindannyian földönkívüliek leszünk, akik nemcsak egy egyszerü „Hallo!'-val, hanem fél lábon állva integetéssel köszöntik egymást. Ezután átváltozhatunk elefántokká, akik a „Hallo!” mellé trombitálnak, és így tovább, minél változatosabb a köszönések módja, annál érdekesebb a gyerekek számára. És természetesen annál kevésbé válik tudatossá, hogy amit csinálnak, az ismétlés útján történő tanulás.

Ez a játék végigkísérheti a további évek nyelvtanulását is, egyre magasabb szintű tartalmakkal feltöltve. Még első osztályban, de már a második félévben képesek a gyerekek alapvető, személyre vonatkozó kérdéseket feltenni, azokat megválaszolni. Így riporterekként indulnak útjukra, amikor megszólal a zene. Mivel egy jó riporter megfelelően felkészül az interjúra, ők sem indulnak üres kézzel, hanem az alábbi képek segítenek a megfelelő kérdést feltenni (az egyes oldalak alatt az ezek által előhívandó mondatok állnak): 


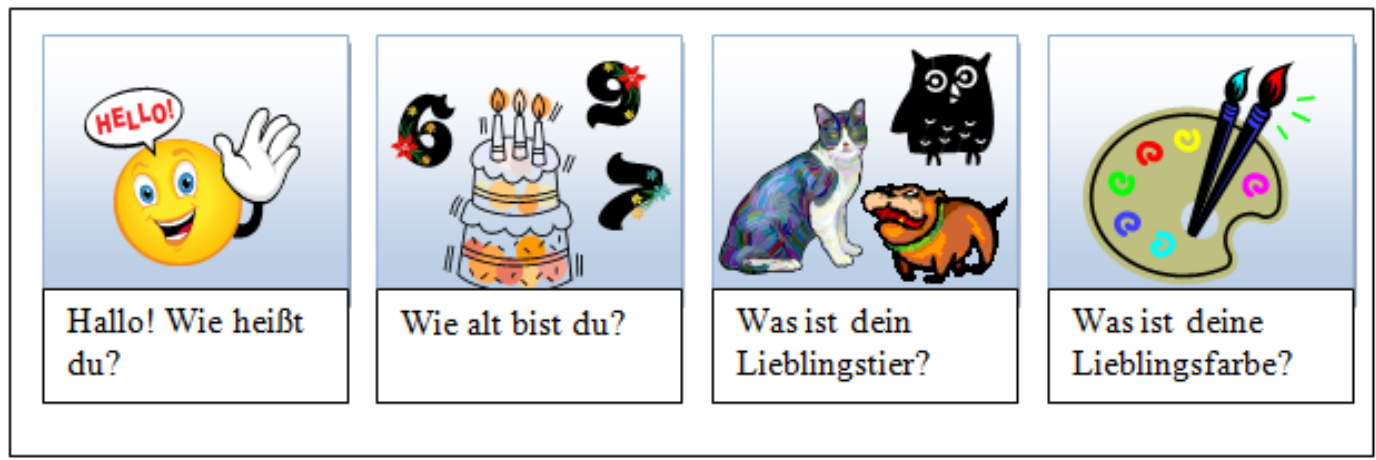

1. ábra: Képek és kérdések a kis 'riporterek' számára

Egyesekben felmerülhet a kétely a gyakorlat hatásosságával kapcsolatban - hiszen nem állhatunk ott minden tanuló mellett egyidejüleg - különösen, ha a lejátszó ki- és bekapcsolására is oda kell figyelnünk -, és nem ellenőrizhetjük minden egyes tanuló megszólalásait. A gyerekek rendezetlenül mozognak a teremben, biztosan elhangzik egy-egy szó az anyanyelvükön is. És valóban, biztosan lesznek 'hibákat' ejtő riporterek, illetve riportalanyok, a tanító nem tud majd minden egyes megszólalást kontrollálni. Ezzel együtt ez a módszer nagyban hozzájárul az óra hatékonyságához, mivel minden gyereknek egyidejüleg lehetősége adódik szabadon beszélni, a többiekre való várakozási idő is megszünik. Nagy szerepe van a nyelvtanulásban a kortársak meghallgatásának is, de ez nem feltétlenül szükséges mindig. És amennyiben párbeszédek eljátszása történik az imént leírt módszerrel, abban természetes módon szerepe van a kivárásnak, a másik meghallgatásának, azaz ebben a szituációban valódi kommunikációs helyzet áll elő.

Szintén párbeszédhez hasonló az a tevékenység, melyben a gyerekek kört alkotva tesznek fel egymásnak kérdéseket - gondolhatunk itt ismét a személyre vonatkozó kérdésekre. Az első kérdező általában a tanító, aki az egyik tanulónak teszi fel kérdését, aki ennek megválaszolása után ismét mást kérdez. Aki válaszolt és kérdezett is, leül, míg az utolsó kérdező is sorra került, és a tanító is válaszolt. Bár a gyerekeknek ez esetben végig kell hallgatni minden választ, érdeklődésüket segít végig fenntartani a véletlen kérdezési sorrend. Az ilyen tevékenységekhez szinte elengedhetetlen kellék egy labda, melyet a kérdés feltevése után egymásnak dobhatnak a gyerekek. Így ismét mozgással köthetjük össze a szövegalkotást, melynek során a gyakorolt 'panelmondatok' még jobban rögzülnek, és mindez játékos szituációban történik.

\subsection{Gyermekdalok, mondókák}

A kezdő szakasz szerves és meghatározó részét képezik az idegen nyelven tanult dalok, mondókák, versek, kiszámolók. E rövid gyermekirodalmi alkotások által nagymértékben gazdagodik a gyerekek szókincse, helyes nyelvi fordulatokat sajátítanak el autentikus szöveg alapján. A dallam és ritmus segítségével mindezek könnyen bevésődnek a gyerekek emlékezetébe, és egyszerüen előhívhatók. Ezen jól ismert előnyök mellett azonban jelentőségük abban is áll, hogy újabb alkalmat adnak a tanulók számára a nyelv használatára. Az ismert szöveg reprodukálása biztonságot jelent a gyerekek számára, különösen a kezdeti szakaszban. Így anélkül, hogy önállóan kellene szöveget alkotniuk, élvezhetik az összefüggő, idegen nyelven való beszéd örömét. Nagyon fontos, hogy az énekeket, verseket kezdetben mindig mozgással kössük öszsze, és mindig a megfelelő mozdulatsorral ismételjük el, hiszen a mozdulat és a szöveg annak jelentésével együtt szorosan összekapcsolódik. 


\subsection{Szituációs játékok, történetek megelevenítése}

Rendkívül fontos már a kezdeti szakaszban, hogy a tanult szavakat, kifejezéseket kontextusban vezessük be, és amint lehet, értelmes szöveg részeként alkalmazzák a gyerekek. Erre ad lehetőséget az alsó tagozat számára készült nyelvkönyvek legtöbbje, a bennük található mesékkel, rövid történetekkel. A történetek megismerése, többszöri meghallgatás után elmélyíthetjük, gyakorolhatjuk a szöveget. Ez utóbbira is számos, változatos ismétlési módszer áll rendelkezésre: a hangzó szöveggel együtt mondva, ismételve, egyénileg, szerepek szerint, különböző hangerősséggel vagy akár elváltoztatott hangon. Ezután a szerepeket felosztva csoportot alakíthatnak a gyerekek, és felkészülhetnek a történet eljátszására.

A különböző szereplők bőrébe bújás nagyban megkönnyíti a gyerekek számára az idegen nyelven való beszédet. Ha az eljátszott történetekben állandó figurák szerepelnek, készíthetünk ezeknek megfelelő maszkokat, melyeket viselve adhatják elő a tanulók a jeleneteket. Így még kézzelfoghatóbbá válik számukra, hogy valaki más szerepében beszélnek, és a hibázástól való félelem is csökken, hiszen a mesefigura 'beszél' az előadáskor. Ugyanilyen hatékony és a tanulók számára biztonságot sugalló lehetőség a történetek bábfigurákkal való eljátszása.

\subsection{Eseménysorok bemutatása, képleírás másként}

A képleírás, képek alapján történő beszélgetés ismert és gyakran alkalmazott módszer. Hogyan tehetjük ezt életszerübbé, valódi élethelyzetekhez hasonlóvá, még hatékonyabbá? Legegyszerübben úgy, ha a bemutatásra kerülő képeket a tanulók saját életükböl, mindennapjaikból vesszük. Ennek többféle módja lehetséges, a legkézenfekvőbb és legelérhetőbb az, ha a gyerekek maguk rajzolnak az adott témáról, és ezt mutatják be a tanult szavakkal, kifejezésekkel a meghatározott munkaformában - párokban vagy csoportban. Sokkal érdekesebb lehet azonban a tanulók által készített fotók használata. Ha tanítványainknak és nekünk lehetőségünk van rá, használjuk ki a technikai eszközök nyújtotta elönyöket, hogy a gyerekek fényképek segítségével valóban saját mindennapjaikból mutathassanak be egy-egy darabot. Itt egy olyan példát mutatnék be, mely bár nem nyelvórán történt, mégis kiválóan alkalmazható a kezdeti szakasz idegennyelv-oktatásában. A tevékenységet először a Heathwood Hall Episcopal School általános iskolájában, Columbiában figyelhettem meg (Amerikai Egyesült Államok, South Carolina). Első osztályos tanulók - nálunk az óvoda utolsó évének megfelelő korosztály - mutatták be ilyen módszerrel egy hétköznapi tevékenységüket, az összefüggő beszédet gyakorolva ezzel. A tanulóknak házi feladatként négy fényképet kellett készíteniük, melyből egy tevékenységsor áll össze. A képeket levetítve mesélték el a gyerekek tevékenységüket kerek mondatokban, lépésről-lépésre. Hogyan alkalmazhatjuk ezt a módszert a nyelvtanítás kezdeti szakaszában azzal a céllal, hogy nőjön a tanórán a gyerekek szóbeli aktivitása? Állon itt erre ismét egy példa, ezúttal saját gyakorlatból, első osztályban. A téma iskolaszerek, a gyerekek feladata ezekkel kapcsolatban egy eseménysor bemutatása. (Példa egy lehetséges képsorozatra: 1. kép: ceruzák a tolltartóban - „Hier ist meine Federmappe. Hier sind meine Stifte.” 2. kép: nyitott tankönyv - „Das ist meine Hausaufgabe.” 3. kép: egyes feladatok már megoldva a könyvben - „Ich schreibe meine Hausaufgabe.” 4. kép: megoldott feladatok - „Die Hausaufgabe ist fertig.”) Az első néhány képsorozatot érdemes beszélgetőkörben bemutatni, hogy minden tanuló számára világos legyen a feladat. Ilyenkor kivetítővel dolgozunk. Különösen akkor, ha nagyobb a csoportlétszám; a 
továbbiakban használjunk kinyomtatott képeket. Ezután a gyerekek páros munkában mutathatják be egymásnak cselekvéssorukat. A tevékenységre hagyjunk elegendő időt, hogy a párok cserélődhessenek is, és egy tanuló többször is elmondhassa 'történetét', illetve minél több társát hallgathassa meg. A tanító eközben minden tanulót egyénileg meg tud hallgatni, javíthat, ha szükséges, így a következő beszélgetésben rögzülnek a helyes mondatok.

\subsection{Kapcsolat partner-tanulócsoporttal a megfelelő nyelvterületröl}

Ma már rengeteg lehetőség adódik arra, hogy egy iskolával, de akár csak egy osztálylyal partnerkapcsolatot alakítsunk ki. A modern technika azt is lehetővé teszi, hogy a gyerekek beszélhessenek, 'személyesen' találkozzanak testvérosztályukkal egy-egy Skype-beszélgetés keretében. Minél fiatalabbak a tanulók, annál precízebb előkészítés szükséges, hogy az anyanyelvi tanulók is tisztában legyenek partnereik szókincsével, nyelvi szintjével, és mindkét fél előtt világos legyen a beszélgetés témája. Egy másodikos angol nyelvet tanuló osztály álljon itt példaként, akiknek azonos korú amerikai beszélgetőpartnerei voltak. A bemutatkozás egyénileg történt, minden tanuló személyesen beszélgetett partnerével (az osztályokon belül minden tanulónak egy, illetve két partnere lehetett az eltérő létszám miatt). Ezután mindkét osztály bemutatott valamit saját kultúrájából: egy közös éneket, verset vagy hangszeren játszott zenét.

$\mathrm{Az}$ anyanyelvi kortársakkal való személyes beszélgetés értéke felbecsülhetetlen. Nemcsak azért, mert valóságos szituációt hoz be az osztályba, hanem leginkább azért, mert a gyerekek számára aligha elképzelhető nagyobb motiváció, mint kortársai megértése akár egy másik kontinensről. Egy-egy ilyen beszélgetés folyamán a gyerekek számára is egyértelművé válik az idegen nyelven kommunikálni tudás értéke.

\section{Összegzés}

A fenti példák segítségével arra kívántam rámutatni, hogy egyrészt a korai idegennyelv-oktatás döntő fontosságú a nyelvtanulás terén, másrészt, hogy ennek leghatékonyabb, sőt kezdetben kizárólagos eszköze a szóbeliség, a tanulók nyelvi aktivitása. Minél fiatalabbak a tanulóink, annál nehezebb lehet erre változatos, a gyerekek számára érdekes, élményszerű tevékenységeket találni. Remélem, az itt összegyűjtött néhány gondolat segíti ebben és újabb ötletek megvalósítására inspirálja a nyelvpedagógust.

\section{Felhasznált irodalom}

Becker, N. (2010): Als Lehrer mitten im lebensnahen Unterricht. Hueber Konferencia, 2010. 08. 28., Budapest.

Kersten, K., Steinlen, A.K., Tiefenthal, C., Wippermann, I. \& Flyman Mattsson, A. (2010): „Guidelines for Language Use in Bilingual Preschools." In K. Kersten, A. Rohde, C. Schelletter, A.K. Steinlen (eds.), Bilingual Preschools. Vol. II: Best Practices. Trier.

Krashen, S. (1982): Principles and Practice in Second Language Acquisition, Prentice-Hall International.

Lenneberg, E.H. (1967):. Biological Foundations of Language. Wiley.

Mampe, B., D. Friederici, A., Christophe, A. \& Wermke, K. (2009): Newborns' cry melody is shaped by their native language. Current Biology

Oyama, S. (1976): „A sensitive period for the acquisition of a nonnative phonological system". Journal of Psycholinguistic Research 
Penfield, W.; Roberts, L. (1959): Speech and Brain Mechanisms. Princeton: Princeton University Press

Singleton, D. \& Lengyel, Zs. (1995, eds.): The age factor in second language acquisition : a critical look at the critical period hypothesis. Clevedon [England]: Philadelphia.

Wermke, K. \& Leising, D. \& Stellzig A. (2007): Relation of melody complexity of infants' cries to language outcome in the second year of life: A longitudinal study. International Journal of Clinical Phonetics \& Linguistics, 21. 11-12., 961-973. 